\title{
Presence of the amphibian chytrid fungus Batrachochytrium dendrobatidis in threatened corroboree frog populations in the Australian Alps
}

\author{
David A. Hunter ${ }^{1,2, *}$, Rick Speare ${ }^{3}$, Gerry Marantelli $^{4}$, Diana Mendez $^{3}, \operatorname{Rod~Pietsch}^{1}$, \\ Will Osborne ${ }^{2}$
}

\author{
${ }^{1}$ NSW Department of Environment, Climate Change and Water, PO Box 733, Queanbeyan, New South Wales 2620 , \\ Australia \\ ${ }^{2}$ Institute for Applied Ecology, University of Canberra, ACT 2601, Australia \\ ${ }^{3}$ Amphibian Disease Ecology Group, School of Public Health and Tropical Medicine, James Cook University, Townsville, \\ Queensland 4811, Australia \\ ${ }^{4}$ Amphibian Research Centre, PO Box 959, Merlynston, Victoria 3058, Australia
}

\begin{abstract}
Since the early 1980s, the southern corroboree frog Pseudophryne corroboree and northern corroboree frog $P$. pengilleyi have been in a state of decline from their sub-alpine and high montane bog environments on the southern tablelands of New South Wales, Australia. To date, there has been no adequate explanation as to what is causing the decline of these species. We investigated the possibility that a pathogen associated with other recent frog declines in Australia, the amphibian chytrid fungus Batrachochytrium dendrobatidis, may have been implicated in the decline of the corroboree frogs. We used histology of toe material and real-time PCR of skin swabs to investigate the presence and infection rates with $B$. dendrobatidis in historic and extant populations of both corroboree frog species. Using histology, we did not detect any $B$. dendrobatidis infections in corroboree frog populations prior to their decline. However, using the same technique, high rates of infection were observed in populations of both species after the onset of substantial population declines. The real-time PCR screening of skin swabs identified high overall infection rates in extant populations of P. corroboree (between 44 and $59 \%$ ), while significantly lower rates of infection were observed in low-altitude $P$. pengilleyi populations $(14 \%)$. These results suggest that the initial and continued decline of the corroboree frogs may well be attributed to the emergence of $B$. dendrobatidis in populations of these species.
\end{abstract}

KEY WORDS: Amphibian declines · Corroboree frog · Amphibian chytrid fungus Resale or republication not permitted without written consent of the publisher

\section{INTRODUCTION}

Over the past $50 \mathrm{yr}$, extinctions and declines of amphibian species worldwide have been occurring at an alarming rate (Stuart et al. 2004). Within Australia, 8 frog species have not been seen in the wild since their initial observed declines, and a further 32 species have declined to levels warranting listing as either vulnerable or endangered (Hero \& Morrison 2004). These declines have primarily occurred along the eastern ranges of Australia, from the alpine regions in the southern highlands to the wet tropics rainforest regions of North Queensland (see reviews in Campbell 1999). While frog declines in North Queensland have primarily been documented for upland riverine species (McDonald \& Alford 1999), in southeastern Australia both riverine and pond-breeding species have exhibited rapid population declines from both high and low altitudes (Gillespie \& Hines 1999, Mahony 1999, Osborne et al. 1999). Of particular concern is that 
many of the declines have occurred rapidly from areas of relatively pristine habitat within national parks and other reserve systems (Alford \& Richards 1999, Osborne et al. 1999).

Research into the causes of frog declines within Australia has identified number of potentially contributing factors, including introduced fish species (Gillespie 2001), habitat disturbance (Hero \& Morrison 2004), increased drought frequency (Osborne 1989), increased UV-B radiation (Broomhall et al. 2000), the widespread use of agricultural chemicals (Hamer et al. 2004), and disease (Berger et al. 1998). The most substantial evidence for the cause of amphibian declines from relatively pristine upland environments is that they are the result of an outbreak of a disease known as chytridiomycosis, caused by infection with the amphibian chytrid fungus Batrachochytrium dendrobatidis (Berger et al. 1998, Skerratt et al. 2007). It is hypothesised that this pathogen was recently introduced into the Australian environment (Berger et al. 1998), possibly from South Africa (Daszak et al. 2003, Weldon et al. 2004), which may explain why some species appear to be particularly susceptible to this pathogen. Both genetic (Morehouse et al. 2003, Morgan et al. 2007) and predecline screening for infection (Berger et al. 1998) supports the novel pathogen hypothesis. Although retrospective data are considered by some to be insufficient to settle this issue (McCallum 2005, Rachowicz et al. 2005), a prospective study demonstrated that population declines of upland amphibians in Panama followed the arrival of $B$. dendrobatidis, supporting the epidemic wave hypothesis originally proposed on retrospective data (Lips et al. 2006, 2008).

Two closely related frog species that have undergone recent declines in southeastern Australia are the northern and southern corroboree frogs Pseudophryne corroboree and P. pengilleyi, respectively. Both these species occur in high montane and sub-alpine bog environments, where they typically breed in small ephemeral pools and seepage lines (Osborne 1989). Because the decline of these species initially coincided with a drought period during the early 1980s, it was suggested that drought, causing early pool drying and tadpole mortality, was the primary mechanism for the observed declines (Osborne 1989). However, despite subsequent periods of suitable climatic conditions, these species have continued declining across much of their range (Osborne et al. 1999). P. pengilleyi is currently listed as nationally vulnerable, while $P$. corroboree is listed nationally as endangered. If current population trends continue, $P$. corroboree is likely to become extinct in the wild within the next 5 to $10 \mathrm{yr}$ (D. A. Hunter unpubl. data).
The present study was undertaken as an initial investigation into whether patterns of the emergence of infection with Batrachochytrium dendrobatidis in populations of both corroboree frog species is consistent with the possibility that this pathogen contributed to the initial and continued decline in these species. Histological techniques were used to assess the presence of $B$. dendrobatidis before and after population declines were first observed using preserved museum specimens and material collected from the field. Subsequently, skin swabs and real-time PCR was used to assess prevalence of infection in both species. Realtime PCR is a more sensitive test for $B$. dendrobatidis than histology in experimentally infected frogs (Boyle et al. 2004) and in wild frogs (Kriger et al. 2006) but was not available prior to 2004 .

\section{MATERIALS AND METHODS}

Study species. The southern corroboree frog Pseudophryne corroboree and northern corroboree frog $P$. pengilleyi are closely related species that breed in high montane and sub-alpine bog environments in southeastern New South Wales, Australia. Male corroboree frogs call from terrestrial nest sites around the edge of ephemeral pools that are typically dry during the summer breeding period. Females lay their eggs in these nest sites, and the eggs develop through to a hatching stage and then enter diapause and await sufficient rains in autumn and winter to flood the nest site and allow the eggs to hatch the tadpoles to move through to the main pool. The tadpoles are then free swimming and feeding until metamorphosis (Anstis 2002).

Survey of archived specimens. Accession lists of archived specimens of both species held in the Australian National Wildlife Collection (ANWC) and the Australian National Museum (ANM) were obtained and a toe taken from all ANWC specimens and $35 \%$ of ANM specimens for histological examination. Archived frogs had been collected solely for the purpose of museum acquisition and availability for subsequent study and were presumed to be normal specimens.

Field survey. The locations of male nest sites were determined using the shout-response technique during the peak breeding period in mid-January, which involves shouting loudly at breeding habitat, to which corroboree frogs respond with their threat call (Osborne et al. 1999). The position of responding males is then determined using triangulation and marked with flagging tape for later inspection to locate the male. To avoid disturbing the males during the core breeding period, attempts to locate males were under- 
taken towards the end of the breeding season in midFebruary. Between 1997 and 2000 inclusive frogs were surveyed for chytridiomycosis using the histological examination of toe clips. After the PCR technique became available, frogs were sampled only by swabbing.

The procedure for obtaining toe material in the field involved removing a single toe at the base of the third phalange using a pair of dissecting scissors, and immediately preserving the toe in $70 \%$ ethanol. The swabbing procedure involved holding the frog by the back legs and wiping the frog 3 times on each of the feet, hands, inside and outside of the thighs, and stomach and back region. After the swab sample was taken, a digital photograph was also taken of the belly and throat pattern for each frog so as to check for recaptured individuals during future sampling. The swabs were stored in a cool location (below $10^{\circ} \mathrm{C}$ ) until delivery to the Commonwealth Scientific and Industrial Research Organisation (CSIRO) Animal Health Laboratory in Geelong, Victoria.

Diagnostic techniques. Histology and screening of toe material: Preserved toe material from museum specimens collected prior to 1980 and toe material collected from extant populations between 1997 and 2000 were examined for infection with Batrachochytrium dendrobatidis using histology. The toes collected between 1997 and 2000 were decalcified in $15 \%$ formic acid for $20 \mathrm{~h}$ and then embedded vertically in paraffin wax. The toes obtained from museum specimens were decalcified in $10 \%$ formic acid for $48 \mathrm{~h}$ and then embedded horizontally in paraffin wax. The difference in the initial processing was due to the field-collected toes being originally processed for skeletochronology analysis. The toes were sectioned using a wax microtome to create ribbons of $5 \mu \mathrm{m}$ sections. For the vertically embedded toes, 15 to 20 transversal sections were taken, while for the horizontally embedded toes 8 longitudinal sections were taken from the middle of the toe. The ribbons of sections were placed into a water bath mixed with $2 \%$ laboratory-grade gelatine, and then mounted on a microscope slide. After drying, sections were stained using the routine Mayer's haematoxylin and eosin (H\&E) procedure. The slides were then mounted with a $60 \mathrm{~mm}$ cover-slip. The slides were assessed for $B$. dendrobatidis infection by visually scanning the areas of stratum corneum and stratum granulosum for each toe section using a light microscope set at $200 \times$ magnification, and then $400 \times$ magnification to confirm the presence of $B$. dendrobatidis zoosporangia (following recommended methods by Berger et al. 1999). All histological samples were assessed blind (i.e. no knowledge of collection date) by one of the authors (D. Mendez) who is highly skilled at identifying $B$. dendrobatidis infection using histological techniques.

PCR: The swabs were screened for the presence of Batrachochytrium dendrobatidis DNA using Taqman real-time PCR assay (see Boyle et al. [2004] and Hyatt et al. [2007] for details of this procedure). Inhibitors in samples were detected by use of a DNA amplicon (VICTM dye, Applied Biosystems) not found in nature and if this failed to amplify, it indicated that inhibitors of the PCR reaction were present in the sample (Hyatt et al. 2007). Inhibited samples were then diluted $1: 10$ or 1:100 and retested in an attempt to dilute the inhibitor below a critical threshold. If dilution was unsuccessful, the result was recorded as sample inhibited.

Statistical analysis. Uncertainty around the total proportion of adults testing positive for infection with Batrachochytrium dendrobatidis was estimated using a Bayesian approach with uninformative priors. The $95 \%$ credible intervals were propagated using Markov chain Monte Carlo methods with 100000 samples after the first 10000 samples were discarded. This was undertaken using the WinBUGS software package, version 1.4 (MRC and Imperial College of Science, Technology and Medicine) (Spiegelhalter et al. 2003).

Hygiene protocols. The following procedures were undertaken to minimise disease transmission between sites and between individuals within sites. Before entering the sites, all equipment that came into contact with frogs (both directly and indirectly) was sterilised with $90 \%$ ethanol. Each individual frog was handled using a new pair of disposable rubber gloves and a new plastic snap lock bag. Both items were immediately discarded after the frog was processed and a new set used for the next frog. Between processing individual frogs, scissors were sterilised using $90 \%$ ethanol.

\section{RESULTS}

All time periods were not evenly represented by the archived specimens, since there were no corroboree frog specimens collected between 1979 and 1991 available in the museums. The earliest museum specimen we sampled was collected in 1963. Of the 122 pre-1980 museum archived corroboree frog specimens sampled for infection with Batrachochytrium dendrobatidis using histology, no specimens tested positive for infection; whereas, of the 23 archived museum corroboree frogs we sampled that were collected between 1991 and 1993, 14 (61\%) tested positive (Table 1). Of the 389 corroboree frog specimens collected from the field between 1997 and 2000 and sampled using histology, 14 tested positive for infection with $B$. dendrobatidis (Table 1). Because there was no overlap in the $95 \%$ 
Table 1. Pseudophryne corroboree and P. pengilleyi. Results for the histological screening of individuals across populations before and after observed declines in these species. CI: credible interval, nd: no data

\begin{tabular}{|lccccc|}
\hline Period & $\begin{array}{c}\text { No. of } \\
\text { sites }\end{array}$ & $\begin{array}{c}\text { No. of } \\
\text { samples }\end{array}$ & $\begin{array}{c}\text { No. } \\
\text { positive }\end{array}$ & $\begin{array}{c}\text { Proportion } \\
\text { infected }\end{array}$ & $\begin{array}{c}95 \% \\
\text { CI }\end{array}$ \\
\hline $\begin{array}{l}\text { Pseudophryne corroboree } \\
\text { Archived }\end{array}$ & & & & & \\
$1960-1969$ & 2 & 56 & 0 & 0 & $0-0.06$ \\
$1970-1979$ & 3 & 7 & 0 & 0 & $0-0.38$ \\
$1980-1989$ & nd & & & & \\
$1990-1999$ & 2 & 12 & 9 & 0.75 & $0.47-0.91$ \\
$\begin{array}{l}\text { Field } \\
1998-2000\end{array}$ & 5 & 105 & 9 & 0.09 & $0.05-0.15$ \\
P. pengilleyi & & & & & \\
Archived & & & & & \\
$1960-1969$ & 3 & 48 & 0 & 0 & $0-0.07$ \\
$1970-1979$ & 2 & 11 & 0 & 0 & $0-0.27$ \\
$\begin{array}{l}1980-1989 \\
1990-1999\end{array}$ & nd & 11 & 5 & 0.45 & $0.21-0.69$ \\
Field & 3 & 11 & & & \\
$1998-2000$ & 12 & 284 & 5 & 0.02 & $0.01-0.04$ \\
\hline
\end{tabular}

credible intervals, differences between pre1980 and post-1980 infection rates were considered significant for the archived museum specimens (Table 1). Significant differences were also observed between the post-1980 archived specimens, and the specimens collected from the field between 1998 and 2000 (Table 1).

The overall levels of Batrachochytrium dendrobatidis infection determined by realtime PCR screening of skin swabs were very high across remnant population of Pseudophryne corroboree in both 2005 and 2006 (Table 2). Given the considerable overlap in $95 \%$ credible intervals, the differences in the proportion of individuals infected between 2005 and 2006 were not considered significant. Comparisons were not undertaken among populations because of the low number of individuals present/sampled in each population. The overall level of infec-

Table 2. Pseudophryne corroboree. Real-time PCR results for amphibian chytrid fungus sampling undertaken across remnant $P$. corroboree populations in 2005 and 2006. Note: calculation for proportion positive and $95 \%$ credible intervals (95\% CI) excluded inhibited samples

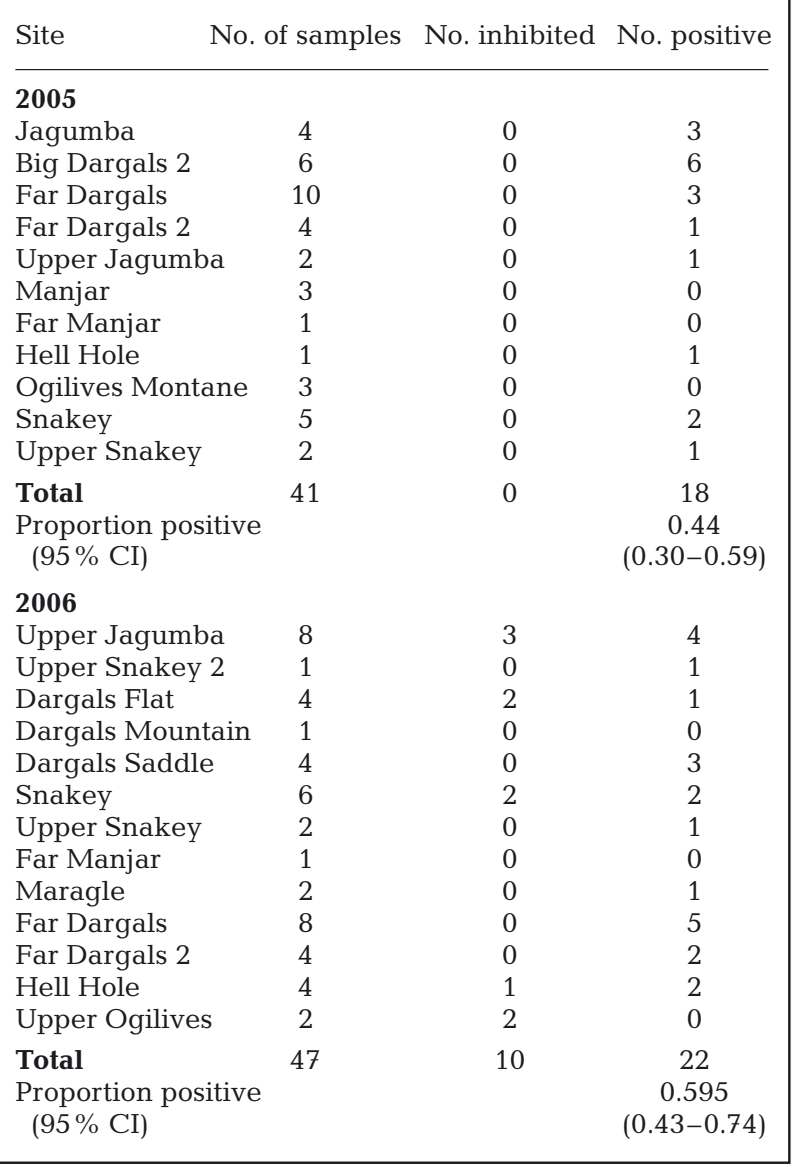

tion observed across $P$. pengilleyi populations in 2006 using real-time PCR screening was significantly lower than infection rates observed across $P$. corroboree populations during 2005 and 2006 (Tables 2 \& 3). High levels of inhibition of the PCR assay were observed across samples in 2006, with the highest inhibition being observed in the $P$. pengilleyi populations (Tables 2 \& 3). Inhibition was not observed in 2005 because samples were diluted until the influence of the inhibitors was negligible (Hyatt et al. 2007).

Table 3. Pseudophryne pengilleyi. Real-time PCR results for amphibian chytrid fungus sampling undertaken across $P$. pengilleyi populations in 2006. Note: calculation for proportion positive and $95 \%$ credible intervals (CI) excluded inhibited samples

\begin{tabular}{|lccc|}
\hline Site & No. of samples & No. inhibited & No. positive \\
\hline Bogong Peaks & 11 & 0 & 2 \\
Big Plain C & 4 & 0 & 0 \\
Big Plain C & 4 & 1 & 0 \\
Big Plain E & 9 & 8 & 1 \\
Big Plain A & 7 & 3 & 0 \\
Devils Peak & 3 & 3 & 0 \\
Brumby Flat & 3 & 1 & 0 \\
Pabral Rd. & 2 & 2 & 0 \\
Cooleman & 15 & 7 & 0 \\
Brindabella & 15 & 10 & 1 \\
Barnets Rd. & 15 & 13 & 0 \\
Broken Cart & 15 & 14 & 0 \\
Micalong Swamp & 21 & 11 & 4 \\
Notingham Rd. & 14 & 11 & 0 \\
Swamp Creek & 11 & 11 & 0 \\
Total & 149 & 95 & 8 \\
Proportion positive & & & 0.14 \\
(95\% CI) & & & $(0.08-0.26)$ \\
\end{tabular}




\section{DISCUSSION}

\section{Distribution and levels of infection in extant corroboree frog populations}

The present study identified the presence of Batrachochytrium dendrobatidis across the distribution of both corroboree frog species (Fig. 1), with considerable variation in infection levels between the 2 species and among the different sampling periods (Tables 1, 2 \& 3). An important feature of these results is the high level of infection observed in very small populations of Pseudophryne corroboree (Table 2). These results have several possible explanations. High infection at low densities may be expected if the pathogen is relatively benign to the host species (Anderson 1979). If $P$. corroboree is susceptible to $B$. dendrobatidis, then this level of infection could be expected if other factors are enhancing infection rates, such as the presence of non-susceptible reservoir host species (Gog et al. 2002, McCallum 2005). Confidently interpreting these results would require information on how infection

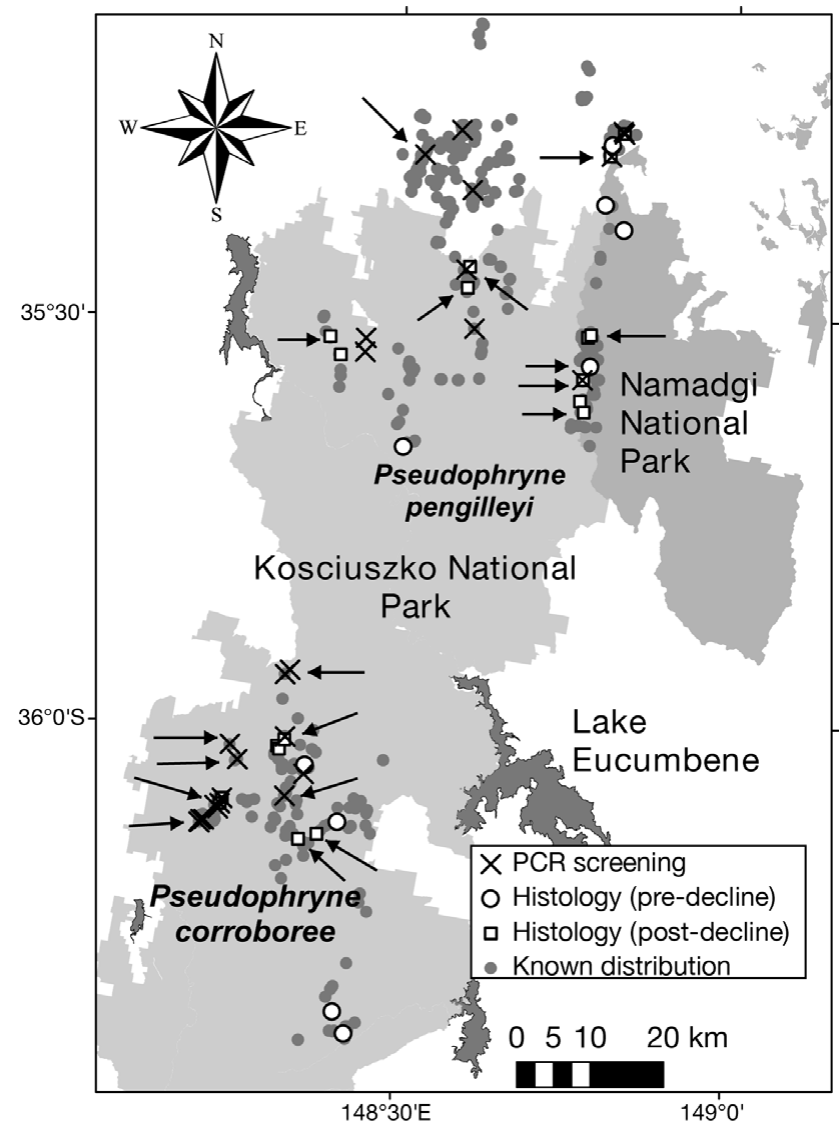

Fig. 1. Location of sites sampled for Batrachochytrium dendrobatidis infection in Pseudophryne corroboree and $P$. pengilleyi populations. Arrows point to sites where positive infection was recorded with this pathogen influences $P$. corroboree survival in the field. P. corroboree certainly appears to be susceptible to this pathogen in captivity (G. Marantelli unpubl. data), however the response of corroboree frogs to infection with this pathogen in captivity may not be indicative of its response in the wild owing to environmental factors.

Another important feature of these results is the significantly lower levels of infection observed in extant Pseudophryne pengilleyi populations compared to extant $P$. corroboree populations (Tables $2 \& 3$ ). This is interesting because monitoring data suggests that many of these $P$. pengilleyi populations have not displayed population declines in recent years to the same extent as $P$. corroboree populations or $P$. pengilleyi populations at higher altitudes (Osborne et al. 1999). If Batrachochytrium dendrobatidis is involved in the continued decline of corroboree frogs, then the different population trajectories observed among different areas may be attributed to variation in rates of infection with $B$. dendrobatidis. While this result may be an artefact of sampling variation associated with fluctuations in detectable infection rates (Berger et al. 2004, Kriger \& Hero 2006), this may also be a plausible hypothesis for a number of reasons. During the breeding season in summer, lower-altitude $P$. pengilleyi populations occupy a warmer and drier environment than P. corroboree populations or high-altitude $P$. pengilleyi populations (Osborne 1989), which are conditions less conducive to $B$. dendrobatidis spread and pathogenicity (Johnson \& Speare 2003, Woodhams et al. 2003, Berger et al. 2004). The potential mechanisms for lower infection in low-altitude $P$. pengilleyi populations, or reduced pathogenicity, should be further investigated, as it may provide critical information about the ecology of $B$. dendrobatidis in corroboree frog populations.

While we observed significant differences in overall infection rates among the 3 main sampling periods when Batrachochytrium dendrobatidis was detected (Tables 1, $2 \& 3$ ), biological explanations for much of this are confounded by the different screening techniques we used among these periods (i.e. histology of archived specimens, histology of field material, PCR screening). PCR has been shown to be a more sensitive test for $B$. dendrobatidis than histology in experimentally infected frogs (Boyle et al. 2004, Hyatt et al. 2007) and in wild frogs (Kriger et al. 2006), and it is possible that the different histological techniques used between the field-collected and archived specimens may have also influenced detectability of infection. With regards to sampling procedures, an important aspect of the results of this study was the high proportion of real-time PCR samples expressing inhibition (Tables 2 \& 3). Hyatt et al. (2007) suggested that one factor increasing the probability of inhibition was the presence of foreign material, such as dirt, on 
the swabs. This may explain our results, because Pseudophryne pengilleyi swabs from populations where high rates of inhibition where observed typically had greater quantities of dirt on them as a result of the frogs at these sites more often occupying partially earthen nest sites, as opposed to the vegetation nest sites at other sites (D. A. Hunter pers. obs.). While repeated dilutions of inhibited samples may reduce the influence of these inhibitors, as was undertaken for the 2005 P. corroboree samples, this procedure may increase the rate of false negative results (A. Hyatt pers. comm.), and also increases the cost per sample.

\section{Presence of the amphibian chytrid fungus pre- and post-decline}

The present study did not detect the presence of Batrachochytrium dendrobatidis in corroboree frog populations prior to observed declines in these species, which began in the early 1980s (Osborne 1989). This is consistent with the results of other Australian studies that have undertaken retrospective screening of preserved frog specimens (Berger et al. 1998, Aplin \& Kirkpatrick 2000), with the earliest record of B. dendrobatidis in Australia being 1978 (Berger et al. 1998). Berger et al. (1998) outlined several possible explanations for not detecting $B$. dendrobatidis in frog populations prior to observed declines, including that this pathogen only recently spread through the Australian environment. Determining whether B. dendrobatidis is a novel pathogen in Australia is fundamental to understanding and responding to frog declines attributed to this pathogen, because the hypothesis that it is endemic and only recently attained increased virulence implies that other factors are likely to be involved and need to be identified. While genetic data (Morehouse et al. 2003, Morgan et al. 2007) and pre-decline screening for infection support the novel pathogen hypothesis, this evidence was not considered sufficiently robust to adequately address this hypothesis by some authors (McCallum 2005). The prospective study by Lips et al. (2006) has weakened arguments against chytridiomycosis not manifesting as an epidemic wave in chytrid-free areas (Skerratt et al. 2007).

As was pointed out by McCallum (2005), the strength of evidence of retrospective screening is limited in supporting the novel pathogen hypothesis. The level of sampling undertaken in the present study was only statistically confident in detecting the presence of Batrachochytrium dendrobatidis if the levels of detectable infection were greater than $0.06 \%$, which overlaps with the $95 \%$ credible intervals for the postdecline infection rates we detected using histology (Table 1). Hence, we are limited in suggesting that $B$. dendrobatidis was not present in the environment prior to these declines. Interpreting pre- and postdecline comparisons is confounded by a range of unknown factors, including the potential for infection to vary greatly between both seasons and years (Berger et al. 2004), and the potential for high rates of false negatives because of the limited sensitivity of histological screening for infection (Kriger et al. 2006). Despite the limitations for supporting the novel pathogen hypothesis, retrospective screening is a very powerful technique for rejecting this hypothesis, as only one positive sample prior to observed declines is required. Hence, retrospective screening should continue to be undertaken as a means to furthering our understanding about the emergence of $B$. dendrobatidis in frog populations.

\section{Disease hypothesis and the decline of the corroboree frogs}

The pattern of decline of corroboree frogs has similarities with the decline of other frog species for which Batrachochytrium dendrobatidis has been suggested as the primary causal agent. The initial decline observed for the corroboree frogs involved a reduction in the breeding adult population size that would have required an increase in adult mortality, not just failed recruitment to metamorphosis (Hunter 2000). Hence hypotheses implicating factors causing mortality during the post-metamorphic stages are more parsimonious than hypotheses involving only failed recruitment to metamorphosis (Scherer et al. 2005). In addition to this, the apparent altitudinal relationship in the observed corroboree frog declines, in combination with the fact that the high-altitude populations are in cooler and moister habitats, is also consistent with the pattern of decline observed in other frog species where B. dendrobatidis has been implicated (Berger et al. 1998, McDonald et al. 2005).

Unlike other studies where Batrachochytrium dendrobatidis has been associated with declining frog populations (Berger et al. 1998, Lips 1999, Lips et al. 2006), sick and/or dead frogs infected with $B$. dendrobatidis have not been located during the monitoring of declining corroboree frog populations. Even if moribund frogs were present in declining corroboree frog populations, locating these individuals may not be expected because these species are typically concealed within vegetation, and sick individuals are unlikely to respond to the survey technique (shout-response). The fact that this study sampled apparently healthy individuals reduces at least one form of sampling bias associated with comparing infection levels between different periods, areas, or species (McCallum 2005). 
There remains some conjecture over the origins of Batrachochytrium dendrobatidis and its role in the decline of frog species along the eastern ranges of Australia (McCallum 2005, Rachowicz et al. 2005). It may not be possible to adequately determine the role of this pathogen in the initial decline of corroboree frogs, because sampling during the early 1980s was not undertaken. Both corroboree frog species now have endemic chytridiomycosis, a situation similar to that which occurred after the epidemic wave in rainforest frogs in central and north Queensland (Retallick et al. 2004, McDonald et al. 2005). Species in central and north Queensland that did not decline rapidly to extinction (Schloegel et al. 2006) appear now to have stabilised and represent an epidemiological pattern of initial declines, partial recovery, and stability. This pattern may be occurring for low-altitude populations of Pseudophryne pengilleyi. However, we hypothesise that $P$. corroboree and high-altitude populations of $P$. pengilleyi are showing a different pattern with a progressive decline, initially rapid, but now at a slower rate (Osborne et al. 1999). This epidemiological pattern will lead to extinction unless the cause can be addressed.

Hence, it is important that research is undertaken to determine whether Batrachochytrium dendrobatidis is contributing to the continued decline of these species and if it is, to take measures to counteract it. Since other frog species in the Australian Alps region underwent similar rapid population declines starting in the early 1980s (Osborne et al. 1999), a coordinated approach to assessing the influence $B$. dendrobatidis on declining alpine frog species would be a more appropriate context. This would not only benefit the implementation of the corroboree frog recovery program, but would make an important contribution to assessing the broader implication of $B$. dendrobatidis to recent frog declines along the eastern ranges of Australia.

Acknowledgements. This research was funded by the NSW Department of Environment and Climate Change. We thank C. De Pagder, C. Smith, M. McFadden, and R. Traher for assistance in the field. A. Hyatt provided valuable advice on the interpretation of results from PCR screening. Ethics approval was provided by the NSW Department of Environment, Climate Change and Water (project no. 041025/03), and this research was conducted with the permission of the New South Wales Parks and Wildlife Service (licence no. S11426).

\section{LITERATURE CITED}

Alford RA, Richards SJ (1999) Global amphibian declines: a problem in applied ecology. Annu Rev Ecol Syst 30: 133-165

Anderson RM (1979) Parasite pathogenicity and the depression of host population equilibria. Nature 279:1026-1029
Anstis M (2002) Tadpoles of south-eastern Australia: a guide with keys. Reed New Holland, Sydney

Aplin K, Kirkpatrick P (2000) Chytridiomycosis in southwestern Australia: historical sampling documents the date of introduction, rates of spread and seasonal epidemiology, and sheds new light on chytrid ecology. In: Getting the jump on amphibian disease. Conference and workshop compendium, Cairns, 26-30 Aug 2000. Available at: www. jcu.edu.au/school/phtm/PHTM/frogs/GJKirk.htm

Berger L, Speare R, Daszak P, Green DE and others (1998) Chytridiomycosis causes amphibian mortality associated with population declines in the rainforests of Australia and Central America. Proc Natl Acad Sci USA 95: 9031-9036

Berger L, Speare R, Kent A (1999) Diagnosis of chytridiomycosis in amphibians by histologic examination. Available at: www.jcu.edu.au/school/phtm/PHTM/frogs/histo/ chhisto.htm

Berger L, Speare R, Hines HB, Marantelli G and others (2004) Effect of season and temperature on mortality in amphibians due to chytridiomycosis. Aust Vet J 82:434-439

Boyle DG, Boyle DB, Olsen V, Morgan JAT, Hyatt AD (2004) Rapid quantitative detection of chytridiomycosis (Batrachochytrium dendrobatidis) in amphibian samples using real-time Taqman PCR assay. Dis Aquat Org 60:141-148

Broomhall SD, Osborne WS, Cunningham RB (2000) Comparative effects of ambient ultraviolet-B radiation in two sympatric species of Australian frogs. Conserv Biol 14: 420-427

Campbell A (ed) (1999) Declines and disappearances of Australia frogs. Environment Australia, Canberra

$>$ Daszak P, Cunningham AA, Hyatt AD (2003) Infectious disease and amphibian population declines. Divers Dist 9: $141-150$

Gillespie GR (2001) The role of introduced trout in the decline of the spotted tree frog (Litoria spenceri) in south-eastern Australia. Biol Conserv 100:187-198

Gillespie GR, Hines HB (1999) Status of temperate riverine frogs in south-eastern Australia. In: Campbell A (ed) Declines and disappearances of Australian frogs. Environment Australia, Canberra, p 109-130

Gog J, Woodroffe R, Swinton J (2002) Disease in endangered metapopulations: the importance of alternative hosts. Proc R Soc Lond B Biol Sci 269:671-676

> Hamer AJ, Makings JA, Lane SJ, Mahony MJ (2004) Amphibian decline and fertilisers used on agricultural land in south-eastern Australia. Agric Ecosyst Environ 102: 299-305

Hero JM, Morrison C (2004) Frog declines in Australia: global implications. Herpetol J 14:175-186

Hunter D (2000) Population demography and conservation of the southern corroboree frog. Masters dissertation, University of Canberra

Hyatt AD, Boyle DG, Olsen V, Boyle DB and others (2007) Diagnostic assays and sampling protocols for the detection of Batrachochytrium dendrobatidis. Dis Aquat Org 73: 175-192

Johnson ML, Speare R (2003) Survival of Batrachochytrium dendrobatidis in water: quarantine and disease control implications. Emerg Infect Dis 9:922-925

Kriger KM, Hero JM (2006) Large-scale seasonal variation in the prevalence and severity of chytridiomycosis. J Zool 2006:1-8

> Kriger KM, Hines HB, Hyatt AD, Boyle DG, Hero JM (2006) Techniques for detecting chytridiomycosis in wild frogs: comparing histology with real-time Taqman PCR. Dis Aquat Org 71:141-148 
Lips KR (1999) Mass mortality and population declines of anurans at an upland site in western Panama. Conserv Biol 13:117-125

Lips KR, Brem F, Brenes R, Reeve JD and others (2006) Emerging infectious disease and the loss of biodiversity in a neotropical amphibian community. Proc Natl Acad Sci USA 103:3165-3170

Lips KR, Diffendorfer J, Mendelson JR III, Sears MW (2008) Riding the wave: reconciling the roles of disease and climate change in amphibian declines. PLoS Biol 6:e72, doi:10.1371/journal.pbio.0060072

Mahony M (1999) Review of the declines and disappearances within the bell frog species group (Litoria aurea species group) in Australia. In: Campbell A (ed) Declines and disappearances of Australian frogs. Environment Australia, Canberra, p 81-93

McCallum H (2005) Inconclusiveness of chytridiomycosis as the agent in widespread frog declines. Conserv Biol 19:1421-1430

McDonald K, Alford R (1999) A review of declining frogs in north Queensland. In: Campbell A (ed) Declines and disappearances of Australian frogs. Environment Australia, Canberra, p 14-22

McDonald KR, Mendez D, Muller R, Freeman AB, Speare R (2005) Decline in the prevalence of chytridiomycosis in upland frog populations in north Queensland, Australia. Pac Conserv Biol 11:114-120

Morehouse EA, James TY, Ganley ARD, Vilgalys R, Berger L, Murphy PJ, Longcore JE (2003) Multilocus sequence typing suggests the chytrid pathogen of amphibians is a recently emerged clone. Mol Ecol 12:395-403

Morgan JAT, Vredenburg VT, Rachowicz LJ, Knapp RA and others (2007) Population genetics of the frog-killing fungus Batrachochytrium dendrobatidis. Proc Natl Acad Sci USA 104:13845-13850

Osborne WS (1989) Distribution, relative abundance and conservation status of corroboree frogs, Pseudophryne corroboree Moore (Anura: Myobatrachidae). Wildl Res 16: 537-547

Editorial responsibility: Alex Hyatt, Geelong, Victoria, Australia
Osborne WS, Hunter DA, Hollis GL (1999) Population declines and range contraction in Australian alpine frogs. In: Campbell A (ed) Declines and disappearances of Australian frogs. Environment Australia, Canberra, p 145-157

Rachowicz LJ, Hero JM, Alford RA, Taylor JW and others (2005) The novel and endemic pathogen hypotheses: competing explanations for the origin of emerging infectious diseases of wildlife. Conserv Biol 19:1441-1448

Retallick RWR, McCallum H, Speare R (2004) Endemic infection of the amphibian chytrid fungus in a frog community post-decline. PLoS Biol 2:e351, doi:10.1371/journal.pbio. 0020351

Scherer RD, Muths E, Noon BR, Corn PS (2005) An evaluation of weather and disease as causes of decline in two populations of boreal toads. Ecol Appl 15:2150-2160

Schloegel LM, Hero JM, Berger L, Speare R, McDonald K, Daszak P (2006) The decline of the sharp-snouted day frog (Taudactylus acutirostris): the first documented case of extinction by infection in a free-ranging wildlife species? EcoHealth 3:35-40

Skerratt LF, Berger L, Speare R, Cashins S and others (2007) Spread of chytridiomycosis has caused the rapid global decline and extinction of frogs. EcoHealth 4: 125-134

Spiegelhalter DJ, Thomas A, Best NG, Lunn D (2003) WinBUGS version 1.4 user manual. Medical Research Council Biostatistics Unit, London

Stuart SN, Chanson JS, Cox NA, Young BE, Rodrigues ASL, Fischman DL, Waller RW (2004) Status and trends of amphibian declines and extinctions worldwide. Science 306:1783-1796

Weldon C, Preez LH, Hyatt AD, Muller R, Speare R (2004) Origin of the amphibian chytrid fungus. Emerg Infect Dis 10:2100-2105

> Woodhams DC, Alford RA, Marantelli G (2003) Emerging disease of amphibians cured by elevated body temperature. Dis Aquat Org 55:65-67

Submitted: April 30, 2008; Accepted: July 12, 2009 Proofs received from author(s): November 20, 2009 